\title{
Lessons from Themes in Professor Johnbull Nigerian Television Drama Season - 4 Episode 9 (Street School) Towards Curtailing Child Abuse in African Societies
}

\author{
Akintoye Festus Ayodimeji
}

Foreign Languages Unit

Afe Babalola University

Ado-Ekiti, Ekiti State, Nigeria

akintoyefa@abuad.edu.ng

Dr. Otunla Adekunle Olusola

Department of Media and Communication Studies

Afe Babalola University

Ado-Ekiti, Ekiti State, Nigeria

otunlad@yahoo.com

\begin{abstract}
Television is a medium through which society is well informed about social reform, social reengineering and social orientation because of the tenacious relevance of its audio-visual influence on the viewers. What people think about nearly every issue be it politics, religion, government, fashion, culture, is almost exclusively influenced by television. Thus, this study examines lessons on re-orientation of the African Society towards curtailing Child Abuse from themes in Professor Johnbull Television Drama, Season 4-Episode nine (Street School). The study identifies various themes of child abuse in the television drama episode using
\end{abstract}


qualitative research approach of textual content analysis through Video preview and review of themes in Prof. Johnbull Television Drama. The study applied the social cognitive theory as well as framing theory. Data were gathered using a researcher-designed instrument named "Video Content Analysis Checklist on Social Orientation and Themes and Framings (VCACSOTF)". Findings from the study revealed that vulnerable children suffer maltreatment such as: Sexual abuse, forced child labour in form of street trading/hawking and child trafficking which is a major setback to the realization of child right act on education in Africa. It recommends that similar Television series and programmes should be produced, identified and sponsored regularly on African Television networks such that social orientation against all forms of child abuse could be spread through various broadcast media just as it is being propagated in Professor Johnbull TV drama episode titled 'Street School'. Further, government in Africa should assist in giving scholarships to indigent and vulnerable street children and that those who participate in child abuse be prosecuted.

Keywords: Social re- orientation, themes, child abuse, Professor Johnbull Television Drama Series.

Introduction

The African society is still growing in terms of socio-cultural, economic and political towards the attainment of human development. The commonest means to achieve this is the use of modern technology such as internet and television to create a simultaneous awareness about a particular malaise that could forestall the growth of Africa. The channel of communication considered in this study is television. Television, that newest and most versatile medium of mass communication burst over post independence Africa like a skyrocket, and like a skyrocket is already leveling off if not coming down. Unlike radio and 
press, television in Africa is almost entirely a product of the years since political independence; in some places television is regarded as a national status symbol comparable to an airline or a presidential palace. A regular television service was established in Morocco in 1954 (for just two years), and in the Western Region of Nigeria in 1959, but the rest of the continent remained almost untouched until 1952, William (1971).

The media plays key role in the construction of child abuse as a major social problem. Moreover, the issue has been covered across a range of genre (including news programmes, TV drama, films, call-in shows, soap operas) thereby reaching a diverse range of audiences. While acknowledging the importance of the media in raising awareness, a number of commentators have also noted that the media's interest is very recent and has generally relied on others that is, activists, professional groups) to lay the groundwork. Rather than being in the vanguard, the media has generally brought up what the public need to know in the society. The groundwork for the recognition of child sexual abuse, for example, laid in early activities by feminists and survivors, and involved international links within the women's movement across the world.

The Media has watchdog roles to play in the society in that it acts as a mirror through which the society can see itself. According to Adekanye (2014), television is considered one of the greatest communication mechanism ever invented and operated by man after the Internet as it influences our perception of politics, religion, movies, governance, fashion and culture and serves as a compact frame that creates an intimate medium because it brings the world into our homes. Television remains the most time consuming activity and main source of news and information, a medium through which politics is conducted, humanity's main form of entertainment, and the world's most powerful sales tool, Adekanye (2014).It is through this medium that society is well informed about social reform, social re-engineering and social orientation because of the tenacious relevance of its audio-visual influence on the 
viewers. In Nigeria, lots of television series have been on air not only focusing on entertainment but informing and educating in order to address and alleviate or put a stop to certain societal ills which implies the presence of social orientation and social reform function in such television series, past and present. These include: Super story; Everyday People; Tales by Moonlight; Tinsel; I need To Know; Jenifa's Diary; and most recently: Professor Johnbull Drama Series.

Therefore, any act that tries to put a stop to certain abnormalities or unnecessary norms in the society is regarded as a social reform. Social reform or social orientation is one of the many facets of social work which serves as the umbrella of various societal services, other aspects include: social service; social justice; social welfare; social health; and social legislation. Social work is a profession which deals various societal problems and issues systematically and scientifically, empowers individuals, groups, and communities, and also requires specific knowledge, skills and techniques to practice,(Nitro,2014) Social reform as a facet of social work is a process through which changes or improvements are made in the society.

It is based on this yardstick that Global Communication sponsors Professor Johnbull Drama series through the medium of television to cater for social orientation in the Nigerian society. The episode under study is season 4 -episode 9 which titled 'Street School'. Season 4 has thirteen hilarious and didactic episodes which fundamental theme focuses on the illmanner of social activities which are nefarious, nebulous, hazardous and anti-social or antihuman for the growth and human development. It is a dynamic drama series that manifest social re-engineering through a channel of Television which is the most major aspect of mass media. This study focuses on season 4-Episode 9(Street School), which showcases the various ways children are abused in this contemporary period. Abuse is a phenomenon and a concept that traumatizes the victims if nothing is done on time to prevent it. Every individual, 
family, and society contributes in any forms of abuse either overtly or covertly. From a largely unacknowledged issue (prior to the 1960s), reportage of child abuse has now reached saturation point (Kitzinger, 2004). Child abuse is a form of maltreatment that is directed or melted towards a minor, that is, a child below eighteen years. Apart from intimate partners' abuse or violence, child abuse is the most trending or the most rampant in our society. However, many works or researches have been done to cater for this ill in the society, but for it to subside or abate; it keeps on increasing and accentuating.

Many studies on child abuse have been carried out in the prints to curb the excesses of this phenomenon (child abuse) by giving social orientation so that people would cease from perpetrating it. Also, lectures have been given against it. This is because children are the hope of tomorrow. They should be built against vices that could jeopardize the growth of a nation. It is on this background that Professor Johnbull TV Drama presented an episode entitled; 'Street School'. In the TV drama, Professor Johnbull gives advice against child labour and vehemently persuades and encourages parents and guardians to discourage children from hawking on the street while their mates are in school. He also gives social orientation against child trafficking and so on and so forth. This act is a way of inculcating the right attitudes on the viewers to have the right social orientation about an ideal society or an ideal societal interaction among the people. However it is a known fact that television is one of the media by which people get information. Television is a major medium through which information is passed to the viewers. It is served as medium through which viewers are entertained, educated and informed about what goes on in the society. Television, by virtue of its audio-visual tendency, people tend to be more comfortable in viewing what is happening in the society. In an increasingly global society, television shapes society's perception of the world ( Pahad, Karkare and Bhatt, 2015). 
Akpan (2008) postulates that what people think about nearly every issue be it politics, religion, government, fashion, culture, is almost exclusively influenced by television. Television broadcasting started in Nigeria in October 1959.The premier of the Western Region, Chief Obafemi Awolowo established the Western Nigeria Television (WNTV) in Ibadan. Television is a new medium that would not only convey messages but convey it accurately with audio and visual details of the message. Media operate within clearly defined environments, which influence the development and growth of the mass media and are, in turn, influenced by the mass media. These environments include social, political, economic, technology and cultural factors that dictate the direction of growth and development of the mass media as social institutions. Through television viewers tend to acquire some behaviors and attitudes, be it good or bad, depending on the content that is being aired or emitted. This is audio-visual capacities to influence attitudinal, social, perceptive and psychological exhibition of characters.

The definitions of childhood vary from country to country and, indeed, religion to religion. The bulk of the countries view childhood in terms of chronological age, while others consider socio economic factors in determining childhood (World Bank, 2005).In some African countries for example, 10 year old apprentices or brides are no longer assumed to possess all the characteristics that industrial countries bundle together into the status of a 'child'. They may be eligible for marriage, but not entitled to make decisions independently of their parents. Different countries invoke different age thresholds of adulthood, even within countries such threshold can diverge-one age for voting, another for employment, and yet another for military services (Satz, 2003).

Child abuse is referred to the kind of maltreatment that a child suffers in the hands of the elderly ones. Abuse can be physical, emotional, and sexual or any treatment that is against 
the good welfare of a child. The World Health Organization (WHO) has defined child abuse and child maltreatment as "all forms of physical and/or emotional ill-treatment, sexual abuse, neglect or negligent treatment or commercial or other exploitation, resulting in actual or potential harm to the child's health, survival, development or dignity in the context of a relationship of responsibility, trust or power. In any epoch, when things go wrong, the media responds in sundry ways to correct the anomaly. Getting things back on track often requires the collaborative effort of all members of the society. One of the veritable strategies for correcting social ills is the massive deployment of mass media specifically the use of television drama. This time proven axiom must have informed the production of the newly debuted TV series by Globacom, Professor Johnbull.

The drama series can be summed up as a response to knotty contemporary issues tearing the fabrics of the Nigerian society apart. Scripted around an erudite academic and martinet, Johnbull Eriweagwuagwu Macathy Macnwigwe aka Professor Johnbull, the series is a satire probing various ills of the society, especially when such vices disrupt the time honoured values the old professor holds in highest esteem. In the maiden episode of the drama series entitled, Claimant, Professor Johnbull, acted by the peerless Kanayo O. Kanayo $(\mathrm{KOK})$, is in his didactic element as he takes a sarcastic swipe at impersonators of celebrities, a rampant vice ravaging the society. It is common these days to see some young folks abandoning the virtue of hard work and adopting a short cut to success through impersonation, name-dropping and other vices. One of the characters in the series, Makuachukwu Ilodibe, who has an arresting resemblance with pop star, Oladapo Daniel Oyebanjo aka D’banj or Kokomaster, impersonates the musician by dressing and speaking like him. Ilodibe, who also displays the trademark mannerisms of the award-winning act, effortlessly swindles unsuspecting members of the public, including the lead character, Professor Johnbull, who relishes using words with 
pedantic pomposity. The chance encounter between the erudite professor and the fake D'banj at a restaurant owned by Olaniyi, played by Yomi Fash Lanso, leads to the professor inviting the phony Kokomaster to his house and extending the unique Igbo hospitality to him and his accomplices.

Professor Johnbull is on a strong foot as a veritable tool for social re-orientation and moral revival in the Nigerian society. The overall concept of the Drama Series is societal sanitation. Sanitation takes centre stage on Professor Johnbull Drama Series. It is on this background the researcher carried out study on the children and social orientation through the television drama series of Professor Johnbull on Nigeria Television Authority (NTA) on Tuesday $8.30 \mathrm{pm}$ to $9.00 \mathrm{pm}$ and the repeat of the broadcast on Friday, $8.30 \mathrm{pm}$ to $9.00 \mathrm{pm}$ as well. This Drama Series is sponsored by telecoms giant, Globalcom. Professor Johnbull Season 4-Episode 9 is all about social orientation on child abuse. For decades some Television Drama Series are being shown for the consumption of the viewers. Some of the TV Drama Series are mentioned as followed: Tinsel, Dear Mother. Gidi Up, Hotel Majestic, Shuga, the Johnsons. Jenifa's Diary, Professor Johnbull, among others.

The recent most popular TV Drama Series, Professor Johnbull, is sponsored by one of the foremost telecommunications company - Global Communication. The drama series reveal the dangers inherent in the unwholesome practices of child labor, child trafficking and street hawking by school-age children. In the latest episode of the sitcom on Nigerian Television Authority Network, NTA International on DSTV Channel 251 and NTA on StarTimes at 8.30 p.m., various ways through which children, minors and other school-age adolescents are abused are dramatized to draw public attention and make the viewers conscious of the deprivations the victims suffer. The episode projects how minors are lured from their homes, especially in the villages, to the cities with the promise of greener pastures and continuation of their education, only to be turned to house helps and street hawkers by 
their masters who renege on all the promises and subject them to all sorts of inhuman treatment.

This is because the harm may have been unintentional, or because the caregivers did not understand the severity of the problem, which may have been the result of cultural beliefs about how to raise a child. Delayed effects of child abuse and neglect, especially emotional neglect, and the diversity of acts that qualify as child abuse, are also factors.

Main Concepts in the Study are: Child right act, child abuse, child labour, child trafficking and child neglect

- The World Health Organization (WHO) defines child abuse and child maltreatment as "all forms of physical and/or emotional ill-treatment, sexual abuse, neglect or negligent treatment or commercial or other exploitation, resulting in actual or potential harm to the child's health, survival, development or dignity in the context of a relationship of responsibility, trust or power (WHO,2014). In the United States, the Centers for Disease Control and Prevention (CDC) uses the term child maltreatment to refer to both acts of commission (abuse), which include "words or overt actions that cause harm, potential harm, or threat of harm to a child", and acts of omission (neglect), meaning "the failure to provide for a child's basic physical, emotional, or educational needs or to protect a child from harm or potential harm". The United States federal Child Abuse Prevention and Treatment Act defines child abuse and neglect as, at minimum, "any recent act or failure to act on the part of a parent or caretaker which results in death, serious physical or emotional harm, sexual abuse or exploitation" or "an act or failure to act which presents an imminent. However, to know exactly who a child is; the following gives an explicit definition of a child. 
- The United Nations (UN) Declaration of the Rights of the Child (DRC) in 1959 builds upon rights that had been set forth in a League of Nations Declaration of 1924. The Preamble notes that children need "special safeguards and care, including appropriate legal protection, before as well as after birth," reiterates the 1924 Declaration's pledge that "mankind owes to the child the best it has to give," and specifically calls upon voluntary organizations and local authorities to strive for the observance of children's rights. One of the key principles in the DRC is that a child is to enjoy "special protection" as well as "opportunities and facilities, by law and by other means," for healthy and normal physical, mental, moral, spiritual, and social development "in conditions of freedom and dignity." The "paramount consideration" in enacting laws for this purpose is "the best interests of the child," a standard echoed throughout legal instruments on children's rights. Among other DRC principles, a child is entitled to a name and nationality; to adequate nutrition, housing, recreation, and medical services; to an education; and, for the handicapped, to "special treatment, education and care." Other principles are on protection against neglect, cruelty and exploitation, trafficking, underage labor, and discrimination.

- Social Cognitive Theory. The social cognitive theory is also called "social Learning, "Observational Learning, "or Modeling because the theory has its roots in psychology, and as a communication theory was developed by Albert Bandura in the 1960's. The theory states that humans learn behaviours by others performing those behaviours and imitating them. In today's increasingly mediate society, the mass media message becomes the source of observational learning. The theory is based on the fact that people observe and imitate influential models around them. This ranges from family members to TV models and cartoon characters. In other words, people can acquire knowledge, emotional reactions and behavioural pattern by observing 
others. The theory states that in order to properly learn from the media a person must be exposed to the media, then be able to encode and remember the event, and lastly be able to translate their perception of the media into an appropriate response.

- Framing Theory was first put forth by Goffman (1974), under the title of Frame Analysis. He put forth that people interpret what is going on around their world through their primary framework. This framework is regarded as primary as it is taken for granted by the user. Its usefulness as a framework does not depend on other frameworks. Goffman states that there are two distinctions within primary frameworks: natural + social. Both play the role of helping individuals interpret data so that their experiences can be understood in a wider social context. The difference between the two is functional. Natural frameworks identify events as physical occurrences taking natural quote literally and not attributing any social forces to the causation of events. Social frameworks view events as socially driven occurrences, due to the whims, goals, and manipulations on the part of other social players (people). Social frameworks are built on the natural frameworks. These frameworks and the frames that they create in our communication greatly influence how data is interpreted, processed, and communicated. Goffman's underlying assumption is that individuals are capable users of these frameworks on a day to day basis whether they are aware of them or not. In Frame Analyses, Erving Goffman provides a platform for understanding and interpreting the interaction between individuals engaging speech communication. In the chapter "The Frame Analyses of Talk," the focus is put on how words are exchanged and what is being said, specifically in informal talk or conversation. The concept of framing is introduced through an exploration of why misunderstandings occur in these basic, everyday conversations, Goffman (1974). He 
argues that they are more errors in verbal framing than anything else. Fairhurst and Sarr (1996) put the framing techniques as followed:

- Metaphor: To frame a conceptual idea through comparison to something else.

- Stories (myths, legends): To frame a topic via narrative in a vivid and memorable way.

- Tradition (rituals, ceremonies): Cultural mores that imbue significance in the mundane, closely tied to artifacts.

- Slogan, jargon, and catchphrase: To frame an object with a catchy phrase to make it more memorable and relate-able.

- Artifact: Objects with intrinsic symbolic value - a visual/cultural phenomenon that holds more meaning than the object itself.

- Contrast: To describe an object in terms of what it is not.

- Spin: to present a concept in such a ways as to convey a value judgment (positive or negative) that might not be immediately apparent; to create an inherent bias by definition.

Statement of the Problem

For decades there has been challenge in child upbringing in many homes in Africa most especially Nigeria. Raising children with high moral values is almost becoming a thing of the past; many parents in Africa just leave their children in the care of anybody without minding what becomes of them. Several attempts have been made to curb the menace of child abuse in African society but instead of the scourge to be abated, it continues to reverberate in every nook and cranny of our society. Therefore, various studies and theories have unraveled that the mass media including the broadcast media play an important role in shaping, building, correcting and reinforcing human behavior; attitudes, perceptions and opinions of 
people who are members of the society. Thus, this study examines lessons on re-orientation of African society towards child abuse eradication from themes in Professor Johnbull Nigerian television drama season 4-episode nine (Street School).

Objectives of the Study

The main objective of the study is to identify social orientation themes on child abuse of Professor Johnbull Television Drama Season 4- Episode Nine. Specific objectives are to:

1. identify social orientation themes portraying out-of-school children in Prof. Johnbull TV drama series.

2. identify social intervention themes against child hawking and child sexual abuse in Prof. Johnbull TV drama series.

3. identify social orientation themes portraying child physical abuse in Prof. Johnbull TV drama series.

4. identify social orientation themes portraying child labour in Prof. Johnbull TV drama series.

5. identify social orientation themes showing child trafficking in Prof. Johnbull TV drama series.

Research Questions:

1. What are social orientation themes portraying out-of-school children in Professor Johnbull TV drama series?

2. What are social intervention themes against child hawking and child sexual abuse in Prof. Johnbull TV drama series?

3. What are the social orientation themes portraying child physical abuse in Prof.Johnbull TV drama series? 
4. What are social orientation themes portraying child labour in Prof.Johnbull TV drama series?

5. What are social orientation themes depicting child trafficking in Prof. Johnbull TV drama series?

\section{Methodology}

The study adopted qualitative approach using textual content analysis of video contents preview and analysis of Professor Johnbull Television Drama. Data were gathered using a researcher-designed instrument named "Video Content Analysis Checklist on Social Orientation Themes and Framing (VCACSOTF)".The checklist contains Social Orientation Themes on Child Abuse, i.e. Sequence; Scene/Discourse; Themes/Portrayal and Pictorial Depiction.

Research Question One: What are social orientation themes portraying out-of -school children in Prof. Johnbull drama series?

Table 1: Analysis of the Theme Depicting and Portraying Out-of-School Children

\begin{tabular}{|l|l|l|l|l|}
\hline S/N & $\begin{array}{l}\text { Sequence in } \\
\text { Seconds /Minute }\end{array}$ & Scene/Discourse & Themes /Portrayal & Pictorial Depiction \\
\hline 1 & $1 \quad$ second- 30 & Secondary school & In-school students \\
\hline 2 & seconds & students on the way & \\
\hline & to school & A school-age boy & Out-of- \\
\hline seconds & hawking bread along & school(child \\
the road looking at & labour) & \\
students going to & & \\
\hline
\end{tabular}




\begin{tabular}{|c|c|c|c|c|}
\hline & & school & & \\
\hline 3 & $\begin{array}{l}1 \text { mins }-1 \text { mins } \\
30 \text { seconds }\end{array}$ & $\begin{array}{l}\text { In a hotel, a man } \\
\text { taking stock of } \\
\text { inventory in his } \\
\text { hotel }\end{array}$ & Hard work & \\
\hline 4 & $\begin{array}{l}1 \text { mins } 31 \text { seconds } \\
-2 \text { mins. }\end{array}$ & $\begin{array}{l}\text { On the street, } \\
\text { Olaniyi is seen play } \\
\text { with Caro on the } \\
\text { street }\end{array}$ & Love and fun & \\
\hline 5 & $\begin{array}{l}2 \text { mins } 1 \text { second- } \\
2 \text { mins } 30 \text { seconds }\end{array}$ & $\begin{array}{l}\text { A woman trafficker } \\
\text { negotiating the price } \\
\text { of the intended } \\
\text { house boy with the } \\
\text { hotelier }\end{array}$ & Child trafficking & \\
\hline
\end{tabular}

Table 1 depicts some children going to school and a school-age boy hawking breads on the street as a result of poverty or no parental care. The theme depicts majorly out-of school children which International Labour Organization (2012) considers as child labour and a form of exploitation and abuse of children especially those that are under-aged and who are supposed to be in school.

Table 2: Analysis of the Theme Depicting and Portraying Social concern about Out-ofSchool Children 


\begin{tabular}{|c|c|c|c|c|}
\hline $\mathrm{S} / \mathrm{N}$ & $\begin{array}{l}\text { Sequence in } \\
\text { Seconds/Minute }\end{array}$ & Scene/Discourse & $\begin{array}{l}\text { Themes } \\
\text { /Portrayal }\end{array}$ & Pictorial Depiction \\
\hline 6 & $\begin{array}{l}\text { 10mins } 1 \\
\text { second-10mins } \\
30 \text { seconds }\end{array}$ & $\begin{array}{l}\text { Olaniyi asks the girl about her } \\
\text { school. She replies that she does } \\
\text { not go to school. Olaniyi asks } \\
\text { about her age. She says she is } \\
\text { 8years old. She immediately } \\
\text { cuts Olaniyi and demands for the } \\
\text { money }\end{array}$ & $\begin{array}{l}\text { Out-of- } \\
\text { school girl; } \\
\text { Preoccupation } \\
\text { with street trading } \\
\text { and errand works }\end{array}$ & \\
\hline 7 & $\begin{array}{l}\text { 10mins } 31 \\
\text { seconds-11 } 1 \text { mins }\end{array}$ & $\begin{array}{l}\text { Olaniyi tells the girl to come } \\
\text { back for the money. }\end{array}$ & $\begin{array}{l}\text { She does not want } \\
\text { to offend her } \\
\text { madam }\end{array}$ & \\
\hline 8 & $\begin{array}{l}11 \text { mins } 1 \text { second- } \\
11 \text { mins } 31 \\
\text { seconds }\end{array}$ & $\begin{array}{l}\text { Olaniyi tells her that she is too } \\
\text { small to argue with him and she } \\
\text { should come back and get her } \\
\text { train }\end{array}$ & $\begin{array}{l}\text { Child audacity to } \\
\text { talk to an elderly } \\
\text { man. }\end{array}$ & \\
\hline 9 & $\begin{array}{l}11 \text { mins } \\
\text { seconds } \\
12 \text { mins }\end{array}$ & $\begin{array}{l}\text { Olaniyi is so concern that the girl } \\
\text { does not go to school. He is } \\
\text { telling this to his } \\
\text { customer; but the } \\
\text { customer pays deaf here to him. }\end{array}$ & $\begin{array}{l}\text { Citizen concern } \\
\text { about out-of } \\
\text { school children. } \\
\text { Some are } \\
\text { lackadaisical } \\
\text { about children } \\
\text { going to school. }\end{array}$ & 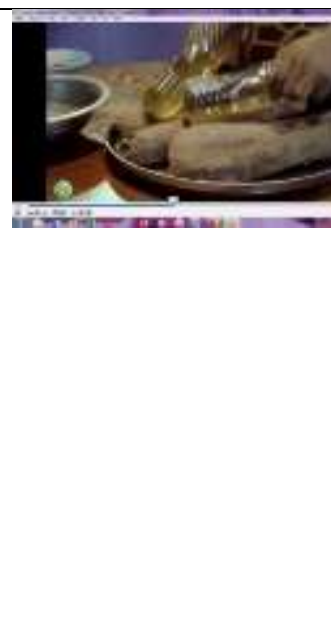 \\
\hline
\end{tabular}




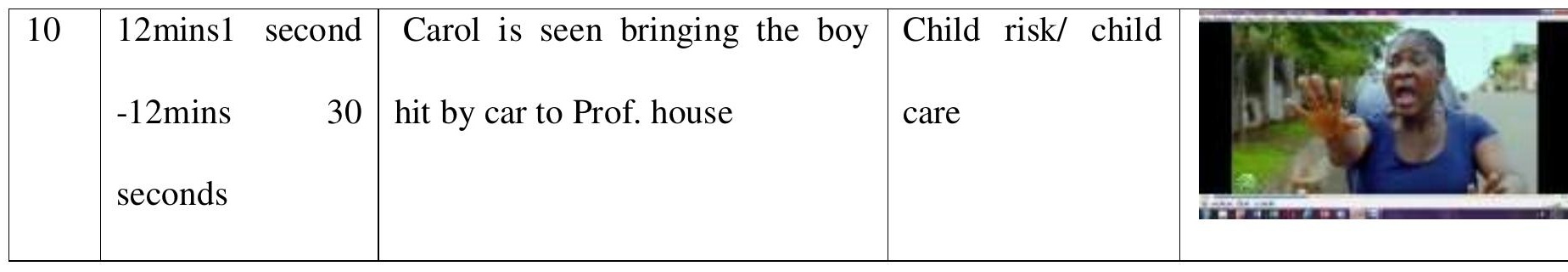

Table 2 portrays the extent to which citizens are concerned about ill-treatment against children in the society. Some children who are supposed to be in school are seen hawking in the street and they are exposed to different kinds of risk such as accident on the road, sexual abuse, psychological abuse, neglect, etc. all these are regarded as one form of abuse or neglect of children according to WHO,(2014),UNICEF,(2016) etc.

Research Question Two: What are social intervention themes against child hawking and child sexual abuse in Prof. Johnbull TV drama series?

Table 3: Analysis of the Theme Depicting and Portraying Social Intervention against Child Hawking and child sexual abuse

\begin{tabular}{|c|c|c|c|c|c|}
\hline $\mathrm{s} / \mathrm{N}$ & $\begin{array}{l}\text { Sequence } \\
\text { Seconds } \\
\text { Minute }\end{array}$ & in & Sicene/Discourse & Themes /Portrayal & Pictorial Depiction \\
\hline 11 & $\begin{array}{l}\text { Mins. } \\
\text { Mins. }\end{array}$ & 31 & $\begin{array}{l}\text { On the street, an } \\
\text { nnderage girl } \\
\text { selling plantain is } \\
\text { escued by flash } \\
\text { rom being } \\
\text { nolested }\end{array}$ & $\begin{array}{l}\text { Social intervention } \\
\text { against child sexual } \\
\text { abuse }\end{array}$ & \\
\hline
\end{tabular}




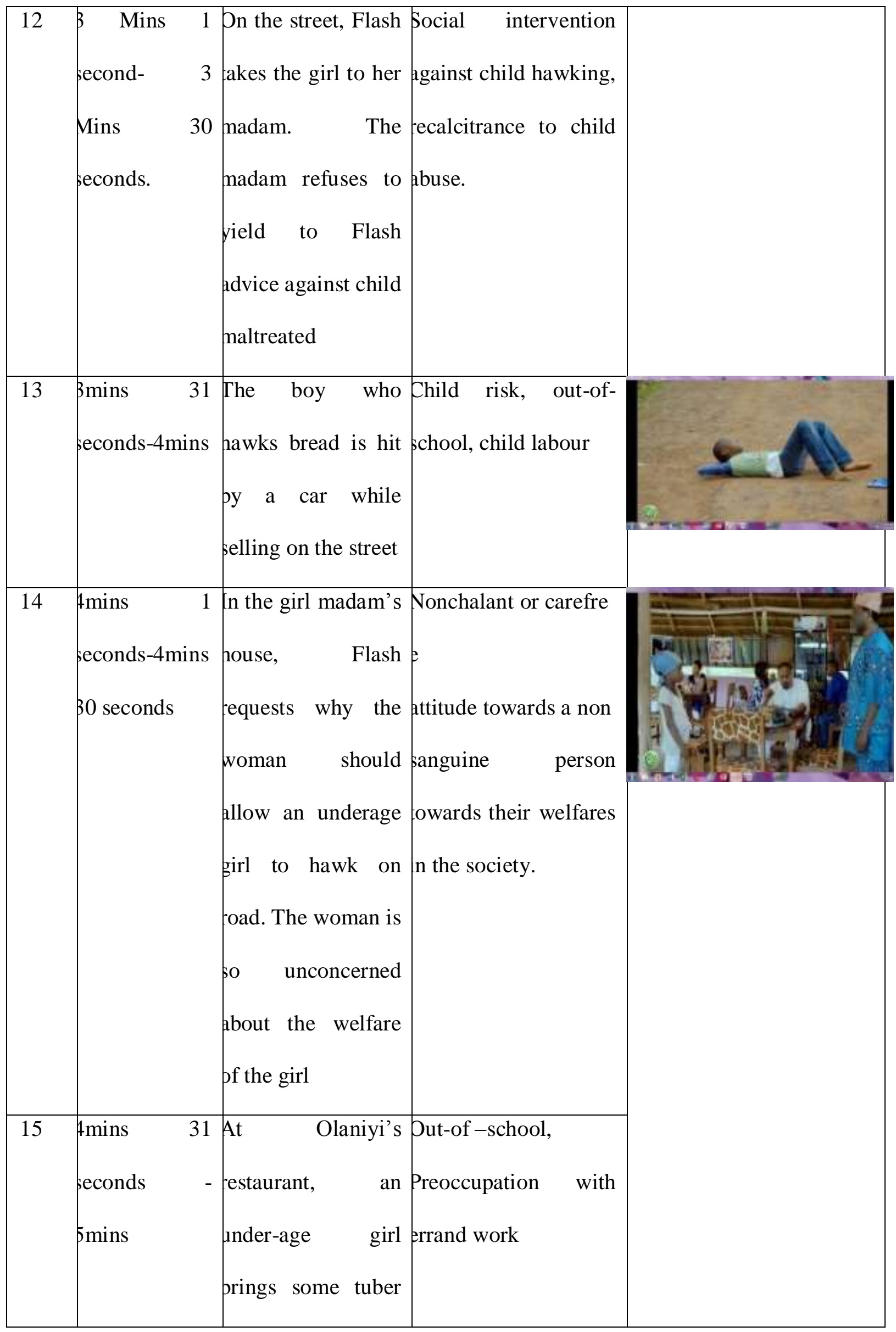




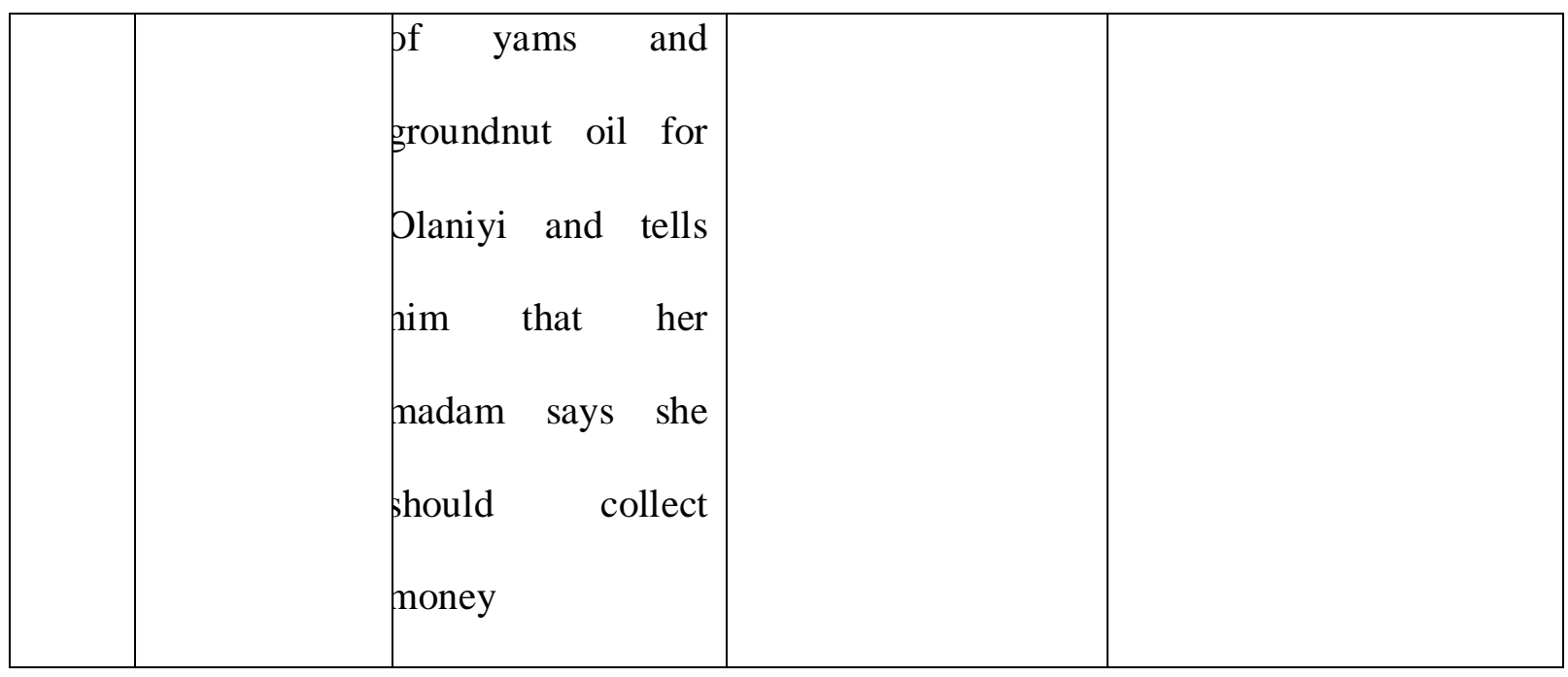

Table 3 shows another theme on social intervention against child street-trading. It depicted in a scene whereby a boy intends to take advantage of a minor who sells plantains with the intention to molest the girl sexually. Also an under-age boy who is supposed to be in school is seen hawking breads in the street and unfortunately was nearly knocked down by a car and immediately he was rescued by Carol; who takes her home for proper attention. Flash (one of the characters) also rescued the under-age girl from being molested. Carol that took care of the boy and Flash that rescued the little girl played social orientation role in the society.

Table 4: Analysis of the Theme Depicting and Portraying Social Intervention against Child Hawking

\begin{tabular}{|l|lr|l|l|l|}
\hline S/N & Sequence in & \multicolumn{2}{l|}{ Scene/Discourse } & Themes & Pictorial Depiction \\
& Seconds/Minute & & Portrayal & \\
\hline 16 & 7 mins 31 & Flash asks the & Social & \\
& seconds -8mins & girl's madam & intervention \\
why she allows a & against child & \\
small girl like & abuse & \\
that to hawk on & & \\
\hline
\end{tabular}




\begin{tabular}{|c|c|c|c|c|}
\hline & & the street. & & \\
\hline 17 & $\begin{array}{l}8 \text { mins } 1 \text { second- } \\
8 \text { mins } \\
\text { seconds }\end{array}$ & $\begin{array}{l}\mathrm{He} \text { tells the } \\
\text { woman that } \\
\text { appropriate } \\
\text { authority will } \\
\text { see to the case. }\end{array}$ & $\begin{array}{l}\text { Report of } \\
\text { child menace } \\
\text { to appropriate } \\
\text { authority }\end{array}$ & 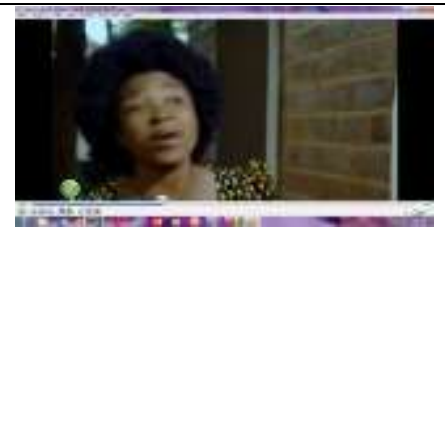 \\
\hline 18 & $\begin{array}{l}8 \text { mins } \\
31 \text { seconds- } \\
9 \text { mins }\end{array}$ & $\begin{array}{l}\text { She justifies } \\
\text { herself of using } \\
\text { the girl as an } \\
\text { errand girl by } \\
\text { saying she feeds } \\
\text { her. She asks if } \\
\text { the girl is } \\
\text { complaining and } \\
\text { then goes inside } \\
\text { the house. }\end{array}$ & $\begin{array}{l}\text { Self } \\
\text { justification } \\
\text { for doing evil }\end{array}$ & L \\
\hline 19 & $\begin{array}{l}\text { 9mins } 1 \text { second- } \\
\text { 9mins } \\
\text { seconds }\end{array}$ & $\begin{array}{l}\text { Flash says he } \\
\text { personally } \\
\text { comes to tongue- } \\
\text { lash and that he } \\
\text { will see that } \\
\text { welfare people } \\
\text { are aware of the }\end{array}$ & $\begin{array}{l}\text { Social } \\
\text { interventions } \\
\text { against child } \\
\text { abuse/Letting } \\
\text { the agent-in- } \\
\text { charge aware } \\
\text { of negligence }\end{array}$ & $\begin{array}{l}1 \\
-\quad \\
0\end{array}$ \\
\hline
\end{tabular}




\begin{tabular}{|c|c|c|c|c|}
\hline & & $\begin{array}{l}\text { evil deeds of the } \\
\text { woman against } \\
\text { child labour. }\end{array}$ & & \\
\hline 20 & $\begin{array}{l}9 \text { mins } \\
\text { seconds } \\
\text { 10mins }\end{array}$ & $\begin{array}{l}\text { At Olaniyi's } \\
\text { restaurant an } \\
\text { underage girl } \\
\text { enters and } \\
\text { delivers tuber of } \\
\text { yams } \\
\text { groundnut oil. } \\
\text { As she enters, } \\
\text { one of Olaniyi's } \\
\text { customers } \\
\text { admires the girl } \\
\text { and says that is } \\
\text { the type of girl } \\
\text { he wants to sell } \\
\text { things for him. }\end{array}$ & $\begin{array}{l}\text { Child trading, } \\
\text { out-of } \\
\text { school girl, } \\
\text { bizarre } \\
\text { interest in } \\
\text { involving } \\
\text { children in } \\
\text { street trading. }\end{array}$ & $\frac{b e s}{6}$ \\
\hline
\end{tabular}

Table 4 shows another of social interventions against child abuse such as street trading, outof -school. Flash demonstrates this by taking the girl to her employer- madam to let her know that what the woman is doing in depriving the girl of proper welfare; anti-social and that she will be reported to appropriate authority for such a heinous act. 
Table 5: Analysis of the Theme Depicting and Portraying Social concern Against Child Abuse Risk

\begin{tabular}{|c|c|c|c|c|}
\hline S/ & $\begin{array}{l}\text { Sequence in } \\
\text { Seconds/Mins. }\end{array}$ & Scene/Discourse & Themes /Portrayal & Pictorial Depiction \\
\hline 21 & $\begin{array}{l}\text { 5mins } 1 \text { second } \\
-5 \text { mins } 30 \\
\text { seconds }\end{array}$ & $\begin{array}{l}\text { Carol brings the } \\
\text { boy that is hit by } \\
\text { the car home } \\
\text { The boy is } \\
\text { searched by } \\
\text { Abadnego, the } \\
\text { security man. }\end{array}$ & $\begin{array}{l}\text { Social intervention } \\
\text { against child risk. }\end{array}$ & \\
\hline 22 & $\begin{array}{l}\text { 5mins } 31 \\
\text { seconds } \\
-6 \text { mins }\end{array}$ & $\begin{array}{l}\text { The hotelier } \\
\text { agrees to pay } \\
\mathrm{N} 8,000 \text { to have } \\
\text { the boy }\end{array}$ & Child trafficking & \\
\hline 23 & $\begin{array}{l}6 \text { mins } 1 \text { second- } \\
6 \text { mins } \\
\text { seconds }\end{array}$ & $\begin{array}{l}\text { Flash rescues } \\
\text { the underage girl } \\
\text { who sells } \\
\text { plantain }\end{array}$ & $\begin{array}{l}\text { Social intervention } \\
\text { against child sexual } \\
\text { abuse }\end{array}$ & \\
\hline 24 & $\begin{array}{l}6 \operatorname{mins} 31 \\
\text { seconds-7mins }\end{array}$ & $\begin{array}{l}\text { The boy selling } \\
\text { breads is hit by } \\
\text { vehicle }\end{array}$ & Child risk & Itis. \\
\hline 25 & $\begin{array}{l}\text { 7mins } 1 \text { second- } \\
7 \text { mins } \quad 30\end{array}$ & $\begin{array}{l}\text { Flash follow the } \\
\text { underage girl }\end{array}$ & $\begin{array}{l}\text { Social concern against } \\
\text { child abuse }\end{array}$ & $\frac{p}{b x}$ \\
\hline
\end{tabular}




\begin{tabular}{|l|l|l|l|l|}
\hline seconds & home & & \\
& & & & \\
\hline
\end{tabular}

Table 5 portrays another theme which is centered on social concern against child abuse. Flash rescues an underage girl who sells plantains from being molested sexually and at the same time he takes the girl (who is living with a woman who is not her mother) home to orientate the woman against street hawking and child abuse.

Research Question 3: What are social orientation themes portraying child physical abuse in Professor Johnbull TV drama series?

Table 6: Analysis of the Theme Depicting and Portraying Child Physical Abuse

\begin{tabular}{|l|l|l|l|l|}
\hline $\mathrm{S} /$ & Sequenc & Scene/Discourse & Themes & Pictorial Depiction \\
$\mathrm{N}$ & e in & Seconds/ & & \\
\hline 26 & 17 mins & On the road, the girl that delivers & Child & \\
& 31 second & goods to Olaniyi is seen crying. & molestation, \\
s-18mins & Olaniyi asks her what the problem is. & child abuse \\
The girl says that her madam asks of & and physical & \\
\hline
\end{tabular}




\begin{tabular}{|c|c|c|c|c|}
\hline & & $\begin{array}{l}\text { the money and when she tells her } \\
\text { that Olaniyi does not give it to her } \\
\text { and that her madam uses turning } \\
\text { stick to hit her on the head. }\end{array}$ & abuse. & \\
\hline 27 & $\begin{array}{l}18 \text { mins } \\
1 \\
\text { second- } \\
18 \text { mins } \\
30 \\
\text { seconds }\end{array}$ & $\begin{array}{l}\text { Hearing this, Prof. Johnbull moves } \\
\text { with annoyance and says" Mon Dieu, } \\
\text { this is preposterous, highly } \\
\text { incredulous..This is repugnance to } \\
\text { natural justice, equity and good } \\
\text { conscience, a slam on her head could } \\
\text { cause a malfunction of her modular } \\
\text { oblongata and lead to cerebral } \\
\text { malfunctions... Prof. friend adds } \\
\text { 'obnoxious'... Olaniyi adds and this } \\
\text { is' kokolicious"' }\end{array}$ & $\begin{array}{l}\text { Concern } \\
\text { against } \\
\text { child } \\
\text { physical } \\
\text { abuse/child } \\
\text { labour }\end{array}$ & 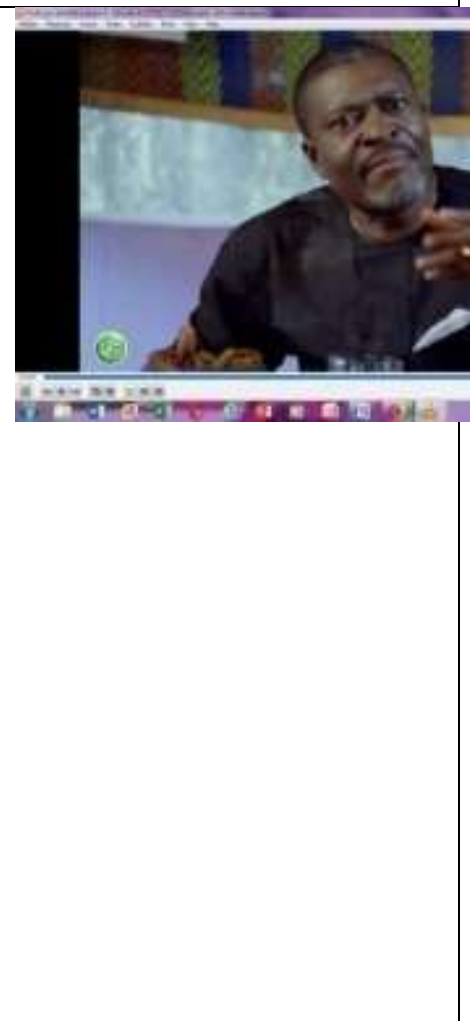 \\
\hline 28 & 19 mins & $\begin{array}{l}\text { Olaniyi imitates prof. in speaking } \\
\text { high sound vocabularies. Prof. } \\
\text { Johnbull asks the girl her age; } \\
\text { Olaniyi says she is } 8 \text { years old which } \\
\text { makes Prof. and his friend believe } \\
\text { that it is Olaniyi harbours her. They } \\
\text { ask her why she does not go to } \\
\text { school. Olaniyi says big men and } \\
\text { women do not send their house boys } \\
\text { and girls to school but they send only }\end{array}$ & $\begin{array}{l}\text { Child } \\
\text { neglect/chil } \\
\text { d inequality/ } \\
\text { child } \\
\text { hawking. }\end{array}$ & - $5 p+b^{\circ}$ \\
\hline
\end{tabular}




\begin{tabular}{|c|c|c|c|c|}
\hline & & their own children. & & \\
\hline 29 & $\begin{array}{l}19 \text { mins } \\
1 \text { second } \\
- \\
\text { 19mins3 } \\
\text { 0seconds }\end{array}$ & $\begin{array}{l}\text { Prof. accuses Olaniyi for not doing } \\
\text { the right thing as regards the case of } \\
\text { the girl and he says the girl must be } \\
\text { taking to an appropriate authority. }\end{array}$ & $\begin{array}{l}\text { Social } \\
\text { intervention } \\
\text { about doing } \\
\text { the right } \\
\text { things } \\
\text { against } \\
\text { child abuse }\end{array}$ & 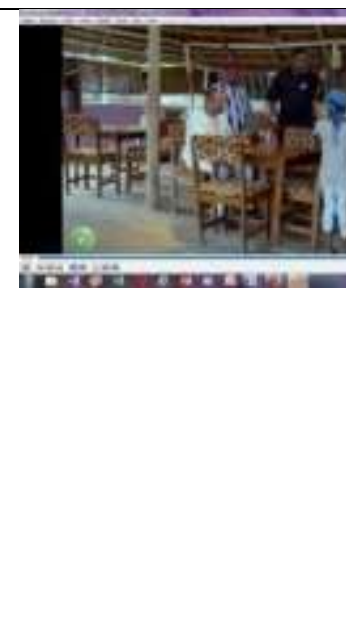 \\
\hline 30 & $\begin{array}{l}19 \text { mins } \\
31 \text { second } \\
\text { s-20 } \\
\text { mins }\end{array}$ & $\begin{array}{l}\text { Olaniyi customer, who is a child } \\
\text { trafficker interjects their } \\
\text { conversation and tells them to leave } \\
\text { the little girl alone. Prof. and his } \\
\text { friend demand to know the man in a } \\
\text { furious mood. Olaniyi begs them to } \\
\text { leave his customer alone. As this is } \\
\text { going on, Churchill and Carol enter } \\
\text { with the boy that is hit by a car }\end{array}$ & $\begin{array}{l}\text { Perpetrator } \\
\text { of child } \\
\text { trafficking. }\end{array}$ & 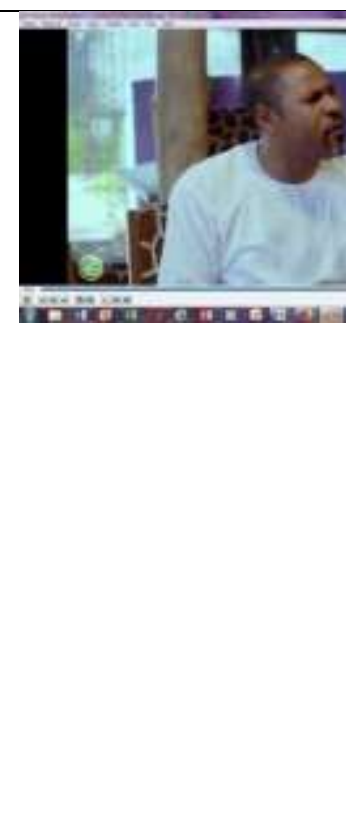 \\
\hline
\end{tabular}

Table 6 portrays themes on child molestation, child abuse; through physical abuse, child neglect and child inequality. Other themes reflected in the table are child hawking, social intervention against child abuse.

Table 7: Analysis of the Theme Depicting and Portraying Child Physical Abuse

\begin{tabular}{|l|l|l|l|l|}
\hline S/ & Sequence in & Scene/Discourse & Themes & Pictorial Depiction \\
\hline
\end{tabular}




\begin{tabular}{|c|c|c|c|c|}
\hline $\mathrm{N}$ & $\begin{array}{l}\text { Seconds/Mi } \\
\text { nute }\end{array}$ & & /Portrayal & \\
\hline 31 & $\begin{array}{l}19 \text { mins } \\
31 \text { seconds- } \\
20 \text { mins }\end{array}$ & $\begin{array}{l}\text { At Olaniyi restaurant while } \\
\text { talk is going on } \\
\text { about maltreatment melted } \\
\text { on an underage out- } \\
\text { of school girl, Churchill and } \\
\text { Carol bring an out-of school } \\
\text { boy who is involved in street } \\
\text { hawking. }\end{array}$ & $\begin{array}{l}\text { Social } \\
\text { intervention } \\
\text { and community } \\
\text { orientation } \\
\text { against any } \\
\text { form of child } \\
\text { abuse }\end{array}$ & \\
\hline 32 & $\begin{array}{l}\text { 20mins } 31 \\
\text { seconds- } \\
21 \mathrm{mins}\end{array}$ & $\begin{array}{l}\text { Churchil says he has been } \\
\text { calling Prof. to tell him about } \\
\text { the case. Prof. responds and } \\
\text { tells him that he has always } \\
\text { tell him that whenever he } \\
\text { wants to eat his phone should } \\
\text { be put aside so that he can } \\
\text { enjoy the meal. }\end{array}$ & $\begin{array}{l}\text { Media social } \\
\text { orientation on } \\
\text { table manners }\end{array}$ & S \\
\hline 33 & $\begin{array}{l}21 \text { mins } \\
\text { second- } \\
21 \text { mins } 30 \\
\text { seconds }\end{array}$ & $\begin{array}{l}\text { The customer asks the little } \\
\text { boy about his breads and } \\
\text { money. Olaniyi tells him to } \\
\text { calm down. }\end{array}$ & $\begin{array}{l}\text { Unrepentant } \\
\text { act/selfishness }\end{array}$ & \\
\hline
\end{tabular}




\begin{tabular}{|c|c|c|c|c|}
\hline 34 & $\begin{array}{l}21 \text { mins } 31 \\
\text { seconds- } \\
22 \mathrm{mins}\end{array}$ & $\begin{array}{l}\text { Olaniyi employs Churchil } \\
\text { and Carol to give the man } \\
\text { breads and money to him if } \\
\text { they have it on them }\end{array}$ & $\begin{array}{l}\text { Advocacy for } \\
\text { peace }\end{array}$ & 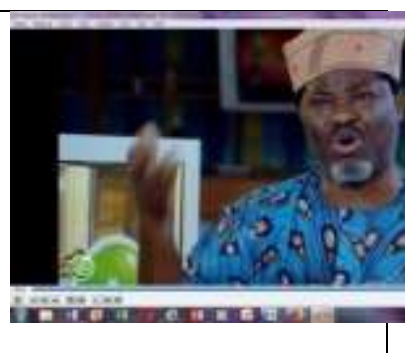 \\
\hline 35 & $\begin{array}{l}22 \text { mins } \\
\text { second- } \\
22 \text { mins } 30 \\
\text { seconds }\end{array}$ & $\begin{array}{l}\text { Churchil is telling him that } \\
\text { the man is a child trafficker. } \\
\text { Olaniyi hearing that quickly } \\
\text { says that he does not know } \\
\text { the man and that he just } \\
\text { comes to his Nkwobi joint } \\
\text { today... }\end{array}$ & $\begin{array}{l}\text { Identification } \\
\text { of child } \\
\text { traffickers in } \\
\text { the society. }\end{array}$ & 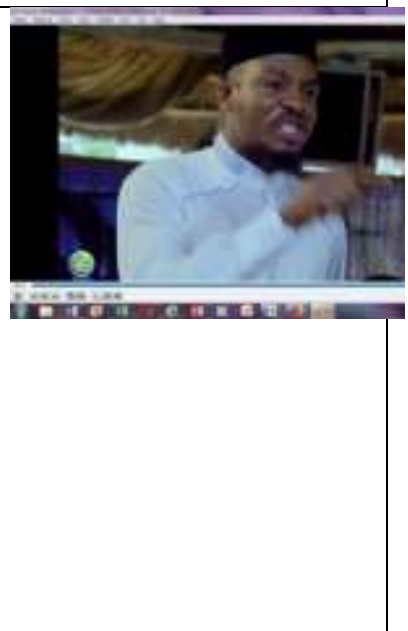 \\
\hline
\end{tabular}

Table 7 portrays the themes of social intervention, community orientation against any form of child abuse, media social orientation on table manner, unrepentant act of a child trafficker, advocacy for peace and identification of child traffickers in the society.

Research Question 4: What are social orientation themes portraying child labour in Professor Johnbull TV drama series?

Table 8: Analysis of Theme - Depicting and Portraying Social Intervention against Child Labour

\begin{tabular}{|l|l|l|l|l|}
\hline S/N & Sequence in & Scene/Discourse & Themes & Pictorial Depiction \\
& Seconds/Minu & & /Portrayal & \\
te & & & \\
\hline
\end{tabular}




\begin{tabular}{|c|c|c|c|c|}
\hline 36 & $\begin{array}{l}\text { 15mins1 secon } \\
\text { d-15mins. } 30 \\
\text { seconds }\end{array}$ & $\begin{array}{l}\text { At Prof. Johnbull's house, } \\
\text { Carol telling Churchill that } \\
\text { the boy is a "mango" and } \\
\text { Churchill corrects her that } \\
\text { the boy is a minor. }\end{array}$ & $\begin{array}{l}\text { Citizens } \\
\text { concern about } \\
\text { injustice } \\
\text { against } \\
\text { children. }\end{array}$ & ritom nums \\
\hline 37 & $\begin{array}{l}\text { 15mins } 31 \\
\text { seconds-16 } \\
\text { mins }\end{array}$ & $\begin{array}{l}\text { At the hotel, the hotelier } \\
\text { asks the woman trafficker } \\
\text { why she brings a minor to } \\
\text { replace his sales rep. This } \\
\text { annoys Samson and asks } \\
\text { the woman why she wants } \\
\text { to bring another person in } \\
\text { his replacement. }\end{array}$ & $\begin{array}{l}\text { Child } \\
\text { trafficking/Chi } \\
\text { ld abuse }\end{array}$ & 酒 \\
\hline 38 & $\begin{array}{l}16 \text { mins } 1 \\
\text { second- } \\
\text { 16mins } 30 \\
\text { seconds }\end{array}$ & $\begin{array}{l}\text { The woman is accuse of } \\
\text { bringing a minor to work as } \\
\text { a sales rep. }\end{array}$ & $\begin{array}{l}\text { Citizens } \\
\text { concern } \\
\text { about child } \\
\text { abuse }\end{array}$ & de IL \\
\hline 39 & $\begin{array}{l}\text { 16mins } 31 \\
\text { seconds- } \\
17 \text { mins }\end{array}$ & $\begin{array}{l}\text { Churchil and Carol trying to } \\
\text { find solution to the issue of } \\
\text { the boy that is hit by a } \\
\text { vehicle }\end{array}$ & $\begin{array}{l}\text { One's brother' } \\
\text { s keeper }\end{array}$ & 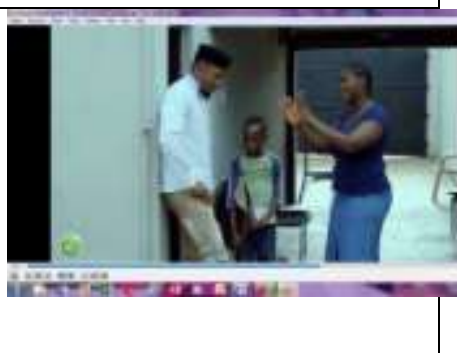 \\
\hline 40 & $\begin{array}{l}\text { 17mins } \\
\text { second- } \\
\text { 17mins } \quad 30 \\
\text { seconds }\end{array}$ & $\begin{array}{l}\text { The woman trafficker is } \\
\text { arrested by the police when } \\
\text { Uduk and his sales rep call } \\
\text { police }\end{array}$ & $\begin{array}{l}\text { Community } \\
\text { concern } \\
\text { against child } \\
\text { abuse }\end{array}$ & 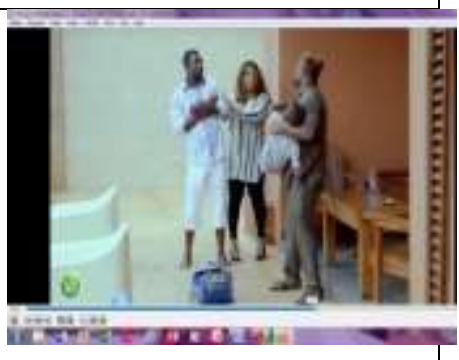 \\
\hline
\end{tabular}


Table 8 shows social intervention against child abuse. Characters such as Carol, Udok, the hotelier and Churchill are seen as concerned citizens saying no to child abuse. Carol and Churchill were fighting against social injustice against child hawking. The woman trafficker is also seen arrested for child trafficking.

Research Question 5: What are social orientation themes depicting child trafficking in Professor Johnbull TV drama series?

Table 9: Analysis of the Theme Depicting and Portraying Child trafficking

\begin{tabular}{|c|c|c|c|}
\hline $\mathrm{S} / \mathrm{N}$ & $\begin{array}{l}\text { Sequence in } \\
\text { Seconds/Minute }\end{array}$ & Themes /Portrayal & Pictorial Depiction \\
\hline 41 & $\begin{array}{l}12 \mathrm{mins} 31 \\
\text { seconds- } 13 \mathrm{mins}\end{array}$ & $\begin{array}{l}\text { Abadnego, the security } \\
\text { man in Prof. Johnbull, } \\
\text { does not trust the child. }\end{array}$ & \\
\hline 42 & $\begin{array}{l}\text { 13mins1 second- } \\
\text { 13mins } 30 \\
\text { seconds }\end{array}$ & $\begin{array}{l}\text { The boy's willingness to } \\
\text { go to school }\end{array}$ & \\
\hline 43 & $\begin{array}{l}13 \text { mins } \\
31 \text { seconds- } \\
14 \text { mins }\end{array}$ & $\begin{array}{l}\text { Laziness on duty/comedy } \\
\text { and hilarity/Child care. }\end{array}$ & a \\
\hline 44 & $\begin{array}{l}\text { 14mins1 second - } \\
\text { 14mins } \\
\text { seconds }\end{array}$ & Indolent attitude at work & 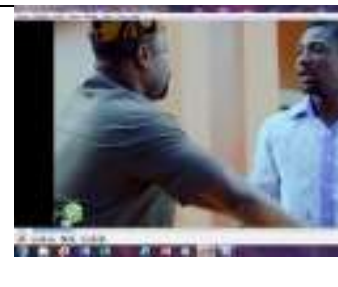 \\
\hline
\end{tabular}




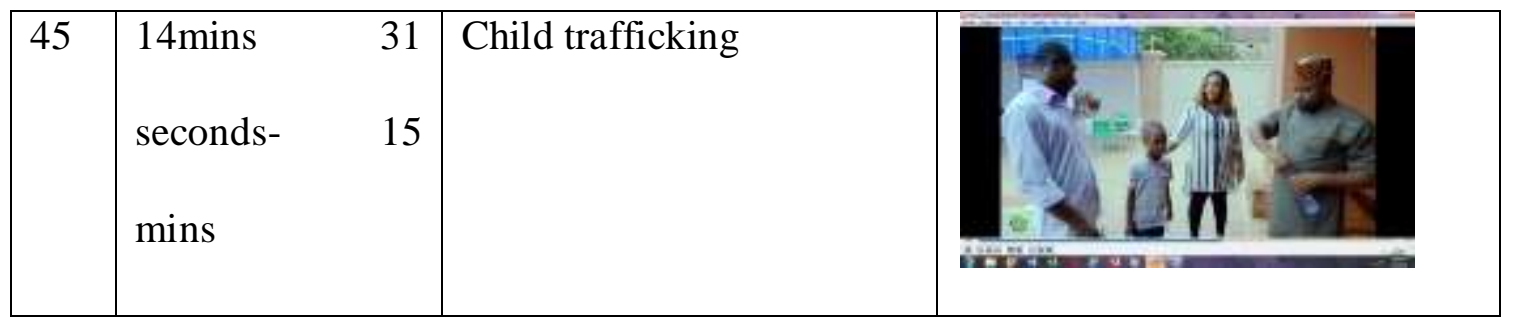

Table 9 portrays another theme on child trafficking; a woman trafficker brings an under-age boy to Udok (an hotelier) as a sales representative. When Udok and his sales representative saw the boy that the woman brought, they immediately called the police to arrest the trafficker.

Table 10: Analysis of the Theme Depicting and Portraying Social Intervention against Child Trafficking.

\begin{tabular}{|c|c|c|c|c|}
\hline $\mathrm{S} / \mathrm{N}$ & $\begin{array}{l}\text { Sequence in } \\
\text { Seconds/Minute }\end{array}$ & Scene/Discourse & Themes /Portrayal & Pictorial Depiction \\
\hline 46 & $\begin{array}{l}22 \text { mins } \\
31 \text { seconds- } \\
23 \text { mins }\end{array}$ & $\begin{array}{l}\text { Churchil tells the } \\
\text { father that the } \\
\text { man } \\
\text { mean."This is his } \\
\text { words. Dad, this } \\
\text { man right here ia } \\
\text { a child trafficker. } \\
\text { He takes young } \\
\text { boys and girls } \\
\text { from the villages } \\
\text { with the promises } \\
\text { to send them to } \\
\text { school... }\end{array}$ & $\begin{array}{l}\text { Social intervention } \\
\text { against child abuse. } \\
\text { Arresting the culprit } \\
\text { of child labour in the } \\
\text { society }\end{array}$ & $\sum_{0}^{2} 2 e^{2}$ \\
\hline
\end{tabular}




\begin{tabular}{|c|c|c|c|c|}
\hline 47 & $\begin{array}{l}\text { 23mins 1 second- } \\
23 \text { mins } \\
\text { seconds }\end{array}$ & $\begin{array}{l}\text { Immediately } \\
\text { Carol takes action } \\
\text { by carrying him } \\
\text { on the shoulder } \\
\text { including } \\
\text { Churchil helping } \\
\text { her to arrest the } \\
\text { man }\end{array}$ & $\begin{array}{l}\text { Arrest of the child } \\
\text { trafficker. }\end{array}$ & 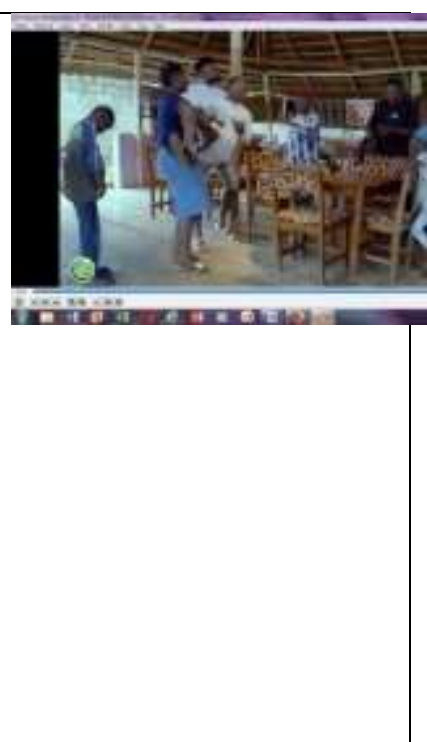 \\
\hline 48 & $\begin{array}{l}23 \min 31 \\
\text { seconds-24mins }\end{array}$ & $\begin{array}{l}\text { Olaniyi begs them } \\
\text { to allow the man } \\
\text { to pay his money } \\
\text { before being } \\
\text { taking to the } \\
\text { prison. He says } \\
\text { after paying his } \\
\text { money he can be } \\
\text { taking to prison } \\
\text { or anywhere. }\end{array}$ & $\begin{array}{l}\text { Concern about one } \\
\text { financial survival and } \\
\text { interest in protecting } \\
\text { children from being } \\
\text { trafficked by cruel } \\
\text { people. }\end{array}$ & 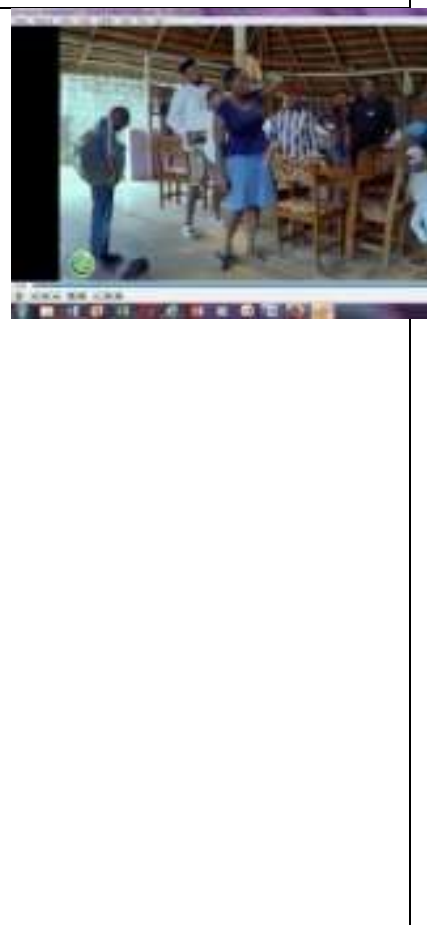 \\
\hline 49 & $\begin{array}{l}24 \mathrm{mins} \\
\text { second- } \\
24 \mathrm{mins} 30 \\
\text { seconds }\end{array}$ & $\begin{array}{l}\text { After this, } \\
\text { Prof.Johnbull } \\
\text { gives his } \\
\text { conclusion by } \\
\text { saying: "Child } \\
\text { labour and } \\
\text { trafficking is at }\end{array}$ & $\begin{array}{l}\text { Denouement on } \\
\text { social orientation on } \\
\text { child abuse.(child } \\
\text { labour, child } \\
\text { trafficking and child } \\
\text { street trading. } \\
\text { Johnbull's cognomen. }\end{array}$ & (3) PROFESSOR's colveuUsiôN \\
\hline
\end{tabular}




\begin{tabular}{|c|c|c|c|c|}
\hline & & $\begin{array}{l}\text { the very peak of } \\
\text { all that is wrong. } \\
\text { So many young } \\
\text { men and women } \\
\text { have had their } \\
\text { dreams snatched } \\
\text { through lies and } \\
\text { deceits of people } \\
\text { who promise } \\
\text { them greener } \\
\text { pastures...encour } \\
\text { aging ... }\end{array}$ & $\begin{array}{l}\text { Children's abilities } \\
\text { should not be } \\
\text { underrated and that } \\
\text { they should be treated } \\
\text { with respect at all } \\
\text { levels. }\end{array}$ & \\
\hline 50 & $25 \mathrm{mins}$ & $\begin{array}{l}\text { Glo } \\
\text { advertisement and } \\
\text { names of cast in } \\
\text { the drama }\end{array}$ & & $\begin{array}{c}8 \text { TIMES } \\
\text { THEVALUE } \\
\text { OF YOUR OECHARE }\end{array}$ \\
\hline
\end{tabular}

Table 10 portrays a scene in Olaniyi's restaurant where a man is arrested for child trafficking. In this scene high level of social justice is displayed by the community people in performing their civil right against injustice on children. Also, Professor Johnbull is seen giving advice to the people against child labour, child trafficking and street trading using children.

\section{Discussion of Findings}

The analysis in the tables portrays the heinous crime committed against children due to lack of parental care. Child trafficking and child labour are the most vices against children 
in the study. The phenomenon of child abuse as shown in the drama includes the following as against the rights of children. Child recruitment, harboring, transportation, provision, or obtaining of a person for labour or servitudes through the use of force or fraud or coercion for the purposes of subjection to involuntary servitude, peonage, debt, bondage, or slavery. This assertion is very germane to all the acts perpetrated against children in the video of Prof. Johnbull. Children are the future adults and because of this fact, they needed to be treated humanely so that there would be better African society. Also, allowing school -age children to be hawking during the school hours should be prohibited by the law enforcement agent. From the drama, it is seen that children who are supposed to be in school are seen hawking in the street and they are exposed to different kinds of risk such as accident on the road, sexual abuse, psychological abuse, neglect and so on and so forth. A school-age boy was almost knocked down by a car before he was rescued as a result of social intervention of concerned citizens.

According to Pinheiro (2006), violence against children involves hitting ('smacking', 'spanking') children, with the hand or with an implement-whip, stick, belt, shoe, wooden spoon, etc. The author states further that corporate punishment can also involve, for example, kicking, shaking or throwing children, scratching, pinching, biting, pulling hair or boxing ears, forcing children to stay in uncomfortable positions, burning, scalding or forced ingestion (for example, washing children's mouths out with soap or forcing them to swallow hot spices).Table 1 to Table 10 answer the question on social re-orientation themes on child abuse in Prof. Johnbull. They show scenes/discourses, themes/portrayal as well as the pictorial depiction of actions in the video. It is shown here that in modern human society, child abuse such as child trafficking, child labour, and child street- trading are prevalent in Nigeria. 


\section{Summary}

This study reveals the general consciousness of Prof. Johnbull Television Drama of social re-orientation on child abuse. The abuse as exemplified in the analysis is the kind of maltreatment that children suffer in the society such as: Sexual abuse, street trading/hawking, child labour, and child trafficking. The advocacy against child abuse through media/television helps viewers including children to be conscious of themselves and their environment. The study found out the ways and manners children are abused and maltreated in Professor Johnbull Drama. It also shows the level of awareness the TV drama series creates in the mind of the viewers, both the old and the young.

\section{Conclusion}

Child labour and trafficking is at the very peak of all that is wrong. So many young men and women have had their dreams snatched through lies and deceits of people who promise them greener-pastures. These children are a blessing and they deserve good education and a safe environment to grow up. Their dreams should not be stolen because they are the leaders of tomorrow. When they are not well taken care of, they become children of the street or in the street as a result of either physical abuse or psychological abuse; and that expose them to any form of dangers. However, it is the responsibilities of every dick and harry in the society to wake up to the challenges of building children the way they should go and when they grow they will not depart from it. Social orientation against any form of child abuse must be spread through any media of communication just as it is being propagated by Prof. Johnbull drama-season 4-episode 9 titled "Street School". Furthermore, everybody in the society is expected to carry out social orientation role in protecting children just as seen in the characters of Churchill, Carol, Flash, Udok, Samson, Olaniyi and Professor Johnbull trying to safeguard children from being molested and abused psychologically. These 
characters play important roles in creating social consciousness and social orientation as well as social intervention against child abuse.

It is high time we had more corporate bodies coming to support the entertainment industry like Globacom is doing. "Professor Johnbull has a huge impact on the society because it is a social satire meant to teach and entertain at the same time.

At the normative level, the concept of a child, implicit in moral and legal practices, is that a child is a person who is in some fundamental ways, not developed but rather developing (Schapiro,1999).In the light of these underdeveloped conditions, adult parents or surrogate are needed to act on children's behalf. Parents or surrogates are thus bestowed with some special obligations including the obligation to protect, nurture, and educate children. These obligations are paternalistic, because adults feel bound to fulfill them, whether the children in question consent to be protected, nurtured, or educated or not. Adults feel justified in treating children paternalistically because children have not yet developed the cognitive, moral and affective capacities to deliberate and act completely in their own interest.

\subsection{Recommendations}

- Arising from the outcome of the study, the following recommendations are put forward:

- Films and movies like Professor Johnbull should be produced and sponsored regularly on natural Television stations.

- Child Rights Acts should be implemented to the letter through intervention of law enforcement Agents.

- Perpetrators of any child abuse should face the music of the law.

- Government should assist by giving scholarships to indigent children 


\section{References}

Adekanye, E. (2014).Television and Academic Performance of Nigerian Youths: Implications for National Development. Journal of Economics and Sustainable Development.Vol.5, No.10,ISSN: 2222-2855.

Akpan,U.(2008).Say You're One of Them: As Africa's Horrors. www.nytimes.com/2008/06/27/b ooks/s.html. Accessed on October 8, 2017.

Bandura, A. (1960).Social Learning Theory: Englewood Cliffs, New Jersey: Pentice-Hall.

Fairhurst, G., \& Sarr, R. (1996). The Art of Framing. San Francisco: Jossey-Bass.

Goffman. E. (1974).Frame Analyses: An Essay on the Organization of Experience Cambridge, MA: Harvard University Press.

Kitzinger, J. (2004).Framing Abuse: Media Influence and Public Understanding of Sexual Violence Against Children. London. Pluto.

NitroPro8 (2014) Chapter2 Origin and Development of Social Work.www.scert.kerala.gov.in /images/2014/HSC-Textbook/34 social work-unit-02.Pdf. Accessed: January 31, 2018.

Pahad, A., Karkare, N., and Bhatt, M. (2015). Influence of Reality Television Shows on Society. In Indian Journal of Applied Research.Vol.5, Issue: 4, April 2015, ISSN2249-555X.

Pinheiro, P. S. (2006)."Violence against children in the home and family" (PDF). World Report on Violence against Children Geneva, Switzerland.

Punch"Professor Johnbull TV Series Delivers Strong Moral” Thisday July, 22 2016. www. thisdaylive.com/index.php/2016/07/22/professor johnbull.

Satz, D. (2003). Child Labour: A Normative Perspective, World Bank Economic Review, Vol.7, No. 12.

The Daily Times: Globacom Professor Johnbull' drama series debut on TV. July 21, 2016. 
U.S. Department of state (2012).Victims of Trafficking and Violence Protection Act of 2012. UNICEF (1992).Children in especially difficult circumstance, UNICEF, Gaborone UNICEF (2005). The State of the World's Children, Oxford University Press.

William A. Hachten (1971).Muffled Drums: The Media in Africa. Iowa State University Press

World Bank (2005). Definition of Childhood. www.uniteforsight.org/genderpower/module4.Accessed on October 8, 2017. 